\title{
Phylogenetic Diversity and Evaluation the Effectiveness of Indigenous Bradyrhizobium Strains for Myanmar Black Gram (Vigna mungo L. Hepper) Cultivars
}

\author{
Khin Myat Soe ${ }^{*}$, Aung Zaw Htwe ${ }^{2}$, Kyi Moe², Tomomi Abiko3 ${ }^{3}$, Takeo Yamakawa4 \\ ${ }^{1}$ Biofertilizer Laboratory, Land Use Division, Department of Agriculture, Ministry of Agriculture, Livestock and Irrigation, \\ Yangon, Myanmar \\ ${ }^{2}$ Department of Agronomy, Yezin Agricultural University, Yezin, Myanmar \\ ${ }^{3}$ Laboratory of Agroecology, Department of Bioresource Sciences, Faculty of Agriculture, Kyushu University, Harumachi, \\ Kasuya-Machi, Kasuya-Gun, Fukuoka, Japan \\ ${ }^{4}$ Laboratory of Plant Nutrition, Department of Bioresource and Bioenvironmental Sciences, Faculty of Agriculture, \\ Kyushu University, Motooka, Nishi-Ku, Fukuoka, Japan \\ Email: *khinmyatsoe@gmail.com, yamakawa@agr.kyushu-u.ac.jp, aungzawhtwe333@gmail.com,kyimoeyau@gmail.com, \\ abikotomomi@farm.kyushu-u.ac.jp
}

How to cite this paper: Soe, K.M., Htwe, A.Z., Moe, K., Abiko, T. and Yamakawa, T. (2020) Phylogenetic Diversity and Evaluation the Effectiveness of Indigenous Bradyrhizobium Strains for Myanmar Black Gram (Vigna mungo L. Hepper) Cultivars. American Journal of Plant Sciences, 11, 285-306. https://doi.org/10.4236/ajps.2020.112022

Received: January 6, 2020

Accepted: February 25, 2020

Published: February 28, 2020

Copyright $\odot 2020$ by author(s) and Scientific Research Publishing Inc. This work is licensed under the Creative Commons Attribution International License (CC BY 4.0).

http://creativecommons.org/licenses/by/4.0/ (c) (i) Open Access

\begin{abstract}
Black gram (Vigna mungo L. Hepper) is one of the main leguminous crops that provide chief source of food. Several Bradyrhizobium species are able to induce effective nodules in black gram cultivars. In the present study, we characterized forty isolates of indigenous black gram bradyrhizobia from Myanmar based on the sequence analysis of the bacterial 16S rRNA gene. The sequence analysis confirmed that all isolates were categorized and identified as the genus Bradyrhizobium and they were conspecific with B. elkanii, B. sp., $B$. liaoningense, $B$. japonicum and $B$. yunamingense. Almost all the collected isolates from major black gram growing regions of Nyaunglebin Bago Regio, Chaungzon Mon State, Sittwe Rakhine State, Danubyu Ayeyarwady Region and Launglon Tanintharyi Region were identified as B. liaoningense. At Danubyu Ayeyarwady Region and Pyinmanar Nay Pyi Taw Region, most of the strains were identified as B. japonicum. On the other hand, more or less all the isolates from Launglon Tanintharyi Region and Hpa-an Kayin State were related to B. elkanii. However, all B. sp. strains were found in Salingyi Sagaing Region black gram growing region. This is the first report describing Bradyrhizobium strains that were isolated from soil samples of major black gram growing areas in Myanmar. Evaluation of the effectiveness of Myanmar Bradyrhizobim strains isolated from soil samples of major black gram growing
\end{abstract}


areas of Myanmar for plant growth and nitrogen fixation was studied in pot experiments with completely randomized design and three replicates. The nodule dry weight, shoot dry weight and acetylene reduction activity of the plant inoculated with Bradyrhizobium elkanii LauBG38 were significantly higher in ARA per plant, nodule and shoot dry weights than the other tested isolates in both Yezin-4 and Yezin-7 black gram varieties. We expect that Myanmar Bradyrhizobium elkanii LauBG38 will be able to use as Biofertilizer for black gram cultivars.

\section{Keywords}

Black Gram, Myanmar, 16S rRNA Gene, Bradyrhizobium, Nitrogen Fixation

\section{Introduction}

Grain legumes play an important nutritional role in the diet of millions of people in the developing countries [1]. Black gram (Vigna mungo L. Hepper) is a short duration crop that belongs to grain legumes family and rich in protein [2]. It is an important legume crop in Asia [3]. In Myanmar, it is one of the major exportable crops and it is the second largest cultivated Legume crop as well [4]. During 2017-2018, black gram growing areas in Myanmar was about 9.77 million hectares with a production of 1.37 metric tons, and the average yield was 1.41 metric ton $\cdot \mathrm{ha}^{-1}[5]$.

Nitrogen (N) fixation through legume-Rhizobium symbiosis is important for enhancing agricultural productivity and is therefore of great economic interest [6]. Leguminous crops have a reputation for maintaining soil fertility since it can assimilate nitrogen from the atmosphere through symbiotic biological $\mathrm{N}_{2}$ fixation (BNF) with Rhizobia [7]. Biological nitrogen fixation (BNF) is an important component of sustainable agriculture [8], and rhizobial inoculants have been applied frequently as biofertilizers.

Rhizobial inoculant can be used to substitute the nitrogenous fertilizers in food legume crops. Recently, peat-based root nodule bacterial inoculants containing TAL strains are using as biofertilizer in seven legumes distributed by Ministry of Agriculture and Irrigation, Myanmar [9]. However, the effectiveness of symbiotic $\mathrm{N}_{2}$ fixation may be an important factor to take into consideration through successful management of symbiosis between black gram cultivars and effective bradyrhizobial strains.

Commercial production of Rhizobium inoculant has been developed for several decades. The main objective of using Rhizobium inoculant is to substitute the nitrogenous fertilizers in food legume production. It is cheaper and lighter in weight than urea and easier to use for the farmers [10]. To improve high quality inoculant production, the evaluation of highly effective rhizobial strains for specific legume is one of the principle obligations [11] [12]. Indigenous rhizobial strains also play an important role since they have adapted to local environmen- 
tal conditions. Therefore, the investigation of effective indigenous rhizobial strains should be considered for current inoculant production in Myanmar.

Myanmar farmers have used, and continue to use, rhizobial inoculants when sowing legumes, but the practice is currently not extensive. The Department of Agricultural Research, Ministry of Agriculture, Livestock and Irrigation is responsible for producing inoculants in Myanmar for their distribution to farmers. Production by DAR peaked during the 1980s at $600-700,000$ packets annually. Current production is $<100,000$ packets, due to limitations in the whole supply chain from production and quality assurance to distribution to demand. Myanmar farmers use nitrogenous $(\mathrm{N})$ fertilizers sparingly, particularly on legume crops. Thus, low-nodulation induced $\mathrm{N}$ deficiencies of the legumes are not remedied by inputs of fertilizer $\mathrm{N}$ and the value of lost production could exceed $\$ 100$ million annually [13].

Several studies also reported significant increase growth parameters and yield due to the inoculation of rhizobial isolates in chickpea [14] in mung bean and in soybean [15] [16] [17] [18] in Myanmar to identify the strains, plant growth and nitrogen fixation. However, there was nobody investigated the native bradyrhizobial isolates from Myanmar black gram cultivars on diversity, plant growth and $\mathrm{N}_{2}$ fixation. So, this research is very first report for phylogenetic diversity and evaluation the effectiveness of indigenous Bradyrhizobium strains for Myanmar black gram (Vigna mungo L.) cultivars and this research finding is needed in order to guarantee the potential of these indigenous Bradyrhizobium strains for black gram production. Not only bradyrhizobial inoculation is important for black gram cultivation by poor Myanmar farmers as valuable cheap source of nitrogen enough $\mathrm{N}_{2}$ fixation by biological means are also necessary and attractive topic for investigation.

For this reason, we aimed to isolate indigenous root nodule bacteria from collected soil samples of major black gram growing areas of Myanmar, to identify the phylogenetic diversity of indigenous black gram-nodulating bradyrhizobia in Myanmar based on sequence analysis of the 16S rRNA region of the isolates, and to evaluate the effectiveness of indigenous Myanmar Bradyrhizobium strains for plant growth and nitrogen fixation of Myanmar black gram varieties are required for investigation.

\section{Materials and Methods}

\subsection{Origin of Soil Sample Collection Sites to Obtain Black Gram Bradyrhizboial Isolates}

Soil samples were collected from eight major black gram growing regions of Myanmar (Figure 1). Meadow soil occurs in Delta Plains Region of Nyaunglebin Bago Region $\left(17^{\circ} 57^{\prime} \mathrm{N} 96^{\circ} 43^{\prime} \mathrm{E}\right)$ with a $\mathrm{pH}$ of 5.04 , Costal Strips Region of Chaungzon Mon State $\left(16^{\circ} 23^{\prime} \mathrm{N} 97^{\circ} 32^{\prime} \mathrm{E}\right)$ with a $\mathrm{pH}$ of 4.69 and Sittwe Rakhine State $\left(20^{\circ} 30^{\prime} \mathrm{N} 93^{\circ} 20^{\prime} \mathrm{E}\right)$ with a pH of 5.91. The Costal Strips Region of Launglon Tanintharyi Region $\left(14^{\circ} 05^{\prime} \mathrm{N} 98^{\circ} 12^{\prime} \mathrm{E}\right)$ with a $\mathrm{pH}$ of 4.79 and Mountain and Hill 


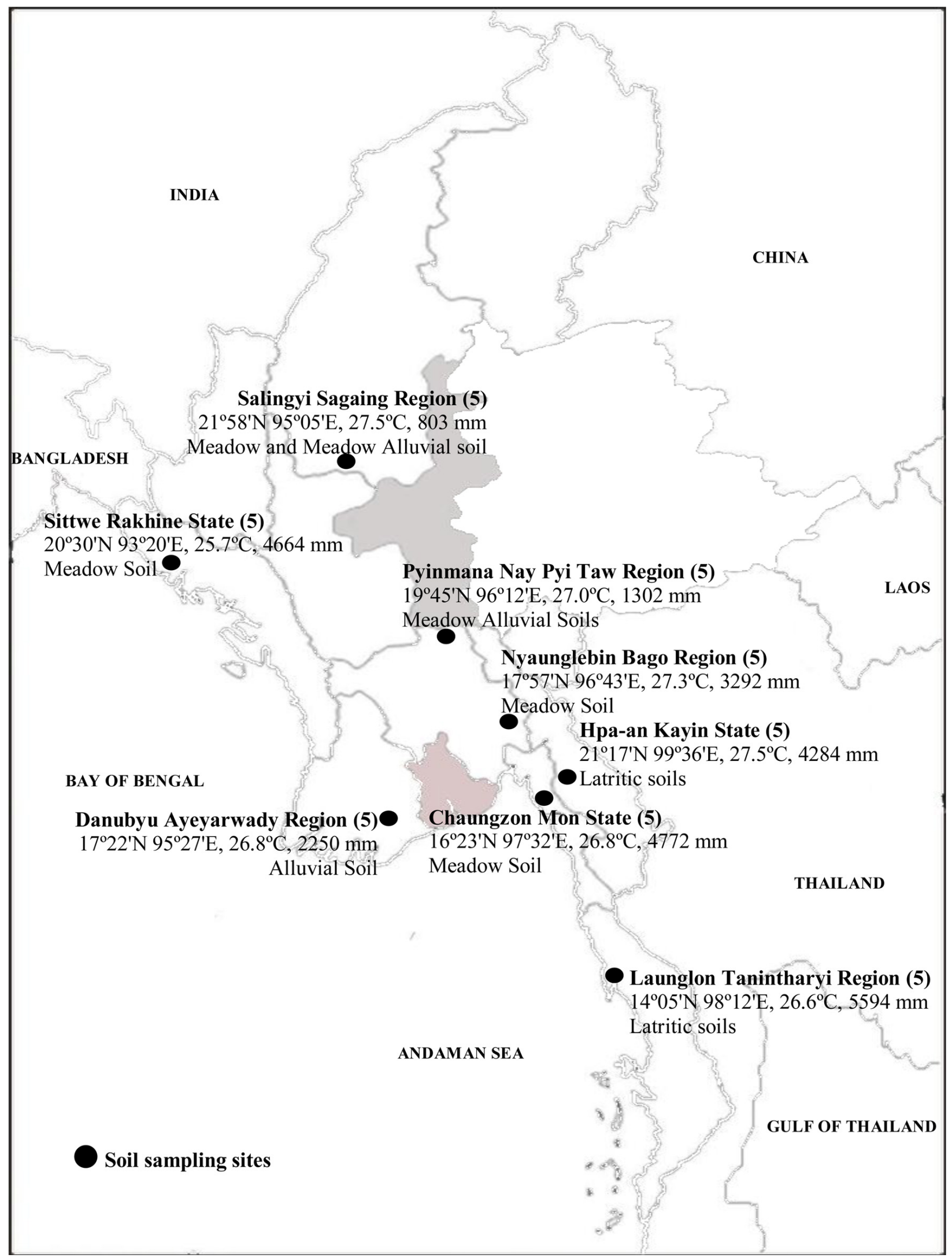

Figure 1. Map of Myanmar showing soil sampling sites from black gram major growing areas in Myanmar. Numbers in parentheses represent the total number of isolates collected from each site. 
Region of Hpa-an Kayin State $\left(16^{\circ} 53^{\prime} \mathrm{N} 97^{\circ} 38^{\prime} \mathrm{E}\right)$ with a $\mathrm{pH} 5.13$ was Latritic Soils [19]. The Central Regions of Pyinmanar Nay Pyi Taw Region $\left(19^{\circ} 45^{\prime} \mathrm{N}\right.$ $\left.96^{\circ} 12^{\prime} \mathrm{E}\right)$ was a Meadow Alluvial Soil with a $\mathrm{pH}$ of 6.01 and Salingyi Sagaing Region $\left(21^{\circ} 58^{\prime} \mathrm{N} 95^{\circ} 05^{\prime} \mathrm{E}\right)$ with a $\mathrm{pH} 6.97$ was Meadow and Meadow Alluvial Soil are performing a tropical wet and dry climate [20]. Alluvial Soil occurs in Delta Plains Region of Danubyu Ayeyarwady Region $\left(17^{\circ} 22^{\prime} \mathrm{N} 95^{\circ} 27^{\prime} \mathrm{E}\right)$ with a $\mathrm{pH}$ of 6.70 (Table 1, Table 2 and Figure 1).

Table 1. Soil classification, location and climate of soil samples collected from major black gram growing areas of Myanmar.

\begin{tabular}{|c|c|c|c|}
\hline Soil sampling site & Soil Classification $^{19)}$ & Location & $\begin{array}{c}\text { Climate }^{20)} \\
\text { (Avg. Temp; RF) }\end{array}$ \\
\hline Nyaunglebin Bago Region & Meadow Soil & $17^{\circ} 57^{\prime} \mathrm{N} 96^{\circ} 43^{\prime} \mathrm{E}$ & $27.3^{\circ} \mathrm{C}, 3292 \mathrm{~mm}$ \\
\hline Danubyu Ayeyarwady Region & Alluvial Soil & $17^{\circ} 22^{\prime} \mathrm{N} 95^{\circ} 27^{\prime} \mathrm{E}$ & $26.8^{\circ} \mathrm{C}, 2250 \mathrm{~mm}$ \\
\hline Chaungzon Mon State & Meadow Soil & $16^{\circ} 23^{\prime} \mathrm{N} 97^{\circ} 32^{\prime} \mathrm{E}$ & $26.8^{\circ} \mathrm{C}, 4772 \mathrm{~mm}$ \\
\hline Launglon Tanintharyi Region & Latritic soils & $14^{\circ} 05^{\prime} \mathrm{N} 98^{\circ} 12^{\prime} \mathrm{E}$ & $26.6^{\circ} \mathrm{C}, 5594 \mathrm{~mm}$ \\
\hline Sittwe Rakhine State & Meadow Soil & $20^{\circ} 30^{\prime} \mathrm{N} 93^{\circ} 20^{\prime} \mathrm{E}$ & $25.7^{\circ} \mathrm{C}, 4664 \mathrm{~mm}$ \\
\hline Pyinmanar Nay Pyi Taw Region & Meadow Alluvial Soil & $19^{\circ} 45^{\prime} \mathrm{N} 96^{\circ} 12^{\prime} \mathrm{E}$ & $27.0^{\circ} \mathrm{C}, 1302 \mathrm{~mm}$ \\
\hline Salingyi Sagaing Region & $\begin{array}{c}\text { Meadow and Meadow } \\
\text { Alluvial Soil }\end{array}$ & $21^{\circ} 58^{\prime} \mathrm{N} 95^{\circ} 05^{\prime} \mathrm{E}$ & $27.5^{\circ} \mathrm{C}, 803 \mathrm{~mm}$ \\
\hline Hpa-an Kayin State & Latritic soils & $16^{\circ} 53^{\prime} \mathrm{N} 97^{\circ} 38^{\prime} \mathrm{E}$ & $27.5^{\circ} \mathrm{C}, 4284 \mathrm{~mm}$ \\
\hline
\end{tabular}

Sources: ${ }^{19}$ Shein, H.A. The soil types and characteristics of Myanmar. Department of Agriculture, Ministry of Agriculture, Livestocks and Irrigation: Nay Pyi Taw, Myanmar, 2015. ${ }^{20)}$ Aung, L.L.; Zin, E.E.; Theingi, P.; Elvera, N.; Aung, P.P.; Han, T.T.; Oo, Y.; Skaland, R.G. Myanmar Climate Report published by Department of Meteorology and Hydrology Myanmar, Ministry of Transport and Communications, Government of the Republic of the Union of Myanmar, 2017.

Table 2. Characteristics of soils used to obtain black gram rhizobia isolate from major black gram growing regions of Myanmar.

\begin{tabular}{|c|c|c|c|c|c|}
\hline \multirow{2}{*}{ Soil samples } & \multicolumn{5}{|c|}{ Physicochemical property } \\
\hline & $\begin{array}{l}\text { Soil pH (Soil: } \\
\left.\mathrm{H}_{2} \mathrm{O} ; 1: 2.5\right)\end{array}$ & $\begin{array}{c}\text { Total N } \\
(\%)\end{array}$ & $\begin{array}{c}\text { Mineralizable } \\
\mathrm{N}(\mathrm{g} / \mathrm{kg})\end{array}$ & $\begin{array}{c}\text { Total } \mathrm{P}_{2} \mathrm{O}_{5} \\
(\%)\end{array}$ & $\begin{array}{c}\text { Total } \mathrm{K}_{2} \mathrm{O} \\
(\%)\end{array}$ \\
\hline Nyaunglebin Bago Region & 5.04 & 0.31 & 1.31 & 0.23 & 1.14 \\
\hline Danubyu Ayeyarwady Region & 6.70 & 0.12 & 0.91 & 0.06 & 0.73 \\
\hline Chaungzon Mon State & 4.69 & 0.23 & 1.57 & 0.10 & 1.74 \\
\hline Launglon Tanintharyi Region & 4.79 & 0.73 & 1.62 & 0.08 & 2.98 \\
\hline Sittwe Rakhine State & 5.91 & 0.16 & 2.07 & 0.05 & 0.42 \\
\hline Pyinmanar Nay Pyi Taw Region & 6.01 & 0.25 & 0.95 & 0.09 & 0.76 \\
\hline Salingyi Sagaing Region & 6.97 & 0.05 & 0.42 & 0.03 & 0.16 \\
\hline Hpa-an Kayin State & 5.13 & 0.16 & 0.75 & 0.07 & 0.75 \\
\hline
\end{tabular}

Soil sample analyses were performed in the plant nutrition laboratory, faculty of agriculture, Kyushu University, Japan. 


\subsection{Analysis of Collected Soil Samples}

The collected soil samples were analyzed at Plant Nutrition Laboratory, Faculty of Agriculture, Kyushu University, Fukuoka, Japan. For each collected soil sample, soil $\mathrm{pH} \mathrm{H}_{2} \mathrm{O}$ (1:2.5 soil: $\mathrm{H}_{2} \mathrm{O}$ ) was measured using a $\mathrm{pH}$ meter (HM-10P; DKK-TOA Corp., Tokyo, Japan). Soil samples were also digested using the salicylic acid-sulfuric acid-hydrogen peroxide method [21]; then, total $\mathrm{N}$ was examined using the indophenol method [22], and total $\mathrm{P}$ was tested using the ascorbic acid method [23]. Total $\mathrm{K}$ was analyzed using an atomic absorption spectrophotometer (Z-5300; Hitachi, Tokyo, Japan) afterward samples were digested. To analyze mineralizable $\mathrm{N}$, we firstly used the soil incubation method [24] followed by the indophenol method [22].

\subsection{Isolation of Indigenous Root Nodule Bacteria from Soil Samples of Major Black Gram (Vigna mungo L.) Growing Areas of Myanmar}

One gram of each composite soil sample was diluted with $99 \mathrm{ml}$ of sterilized one-half strength modified Hoagland nutrient solution (MHN) in a $200 \mathrm{~mL}$ conical flask. The flasks were shaken on a rotary shaker at $120 \mathrm{rpm}$ for one hour to prepare a well-mixed soil suspension. The culture pots (1 L volume) were filled with $1 \mathrm{~L}$ of vermiculite and $0.6 \mathrm{~L}$ of MHN nutrient solution. The pots were covered with aluminum foil and autoclaved at $121^{\circ} \mathrm{C}$ for $20 \mathrm{~min}$. For surface sterilization, the seeds were soaked in a $2.5 \%$ sodium hypochlorite solution for 5 min, rinsed five times with $10 \mathrm{ml}$ of $99.5 \%$ ethanol and washed five times with sterilized MHN nutrient solution to remove traces of sodium hypochlorite and ethanol. Myanmar Yezin-7 black gram variety, common use in Myanmar was used as trap host for all soil samples.

The culture pots using black gram Yezin-7 variety with eight soil suspensions and control pot were prepared. The seeds were surface-sterilized and planted in the sterilized vermiculite pots. $5 \mathrm{ml}$ aliquot of soil suspension was inoculated per seed. The control was planted without inoculation to assess the possibility of contamination. The plants were cultivated in the incubator $\left(25^{\circ} \mathrm{C}\right.$ and 16 hours light) for four weeks. Autoclaved deionized water was poured when the original weight of the pots decreased by around $300 \mathrm{~g}$.

After carefully uprooting, the five nodules ( $\geq 2 \mathrm{~mm}$ in diameter) were collected per pot. For surface sterilization, the nodules were soaked in $70 \%$ ethanol for 3 min, $2.5 \%$ sodium hypochlorite $(\mathrm{NaClO})$ solution for $15 \mathrm{~min}$ and washed five times with $0.9 \%$ autoclaved sodium chloride $(\mathrm{NaCl})$ solution. The surface sterilized nodules were transferred separately into the autoclaved small test tubes and crushed. For every sample, a loopful of the suspension was streaked on Yeast Extract Mannitol Agar (YMA) plates containing 25- $\mu$ g Congo red [25]. The plates were incubated at $30^{\circ} \mathrm{C}$ for $1-3$ days for fast growing bacteria and $5-7$ days for slow growing bacteria. Finally, purified 40 indigenous root nodule bacteria isolates were isolated from soil samples of major Black gram (Vigna mungo 
L.) growing areas of Myanmar. The collected isolates were nominated as HpaBG1 to LauBG40.

\subsection{DNA Extraction, PCR Analysis and Phylogenetic Analysis}

For DNA extraction, the collected isolated were streaked onto A1E agar plates and incubated at $30^{\circ} \mathrm{C}$ for 7 days. A single pure colony of each isolate from $\mathrm{A} 1 \mathrm{E}$ plates was cultured in AIE liquid medium at $30^{\circ} \mathrm{C}$ for 5 days to obtain the required optimum density $\left(0.4<\mathrm{OD}_{600 \mathrm{~nm}}<0.6\right)$. Total DNA was extracted using ISOPLANT (Nippon gene, Tokyo, Japan), following instructions from the manufacturer. The DNA concentrations were calculated using NIH Image 1.62 (National Institutes of Health, Bethesda, MD, USA) after agarose gel electrophoresis (0.3\% agarose gel in 1 TAE buffer), staining with ethidium bromide (Toyobo, Tokyo, Japan), and destaining in 1 TAE buffer.

The primers 16S-F (5'-AGAGTTTGATCCTGGCTCAG-3') and 16S-R2 (5'-CGGCTACCTTGTTACGACTT-3') were used to amplify the $16 \mathrm{~S}$ rRNA region of mesorhizobia. The PCR reaction consisted of a pre-run at $94^{\circ} \mathrm{C}$ for 5 min, denaturation at $94^{\circ} \mathrm{C}$ for $30 \mathrm{~s}$, annealing at $60^{\circ} \mathrm{C}$ for $30 \mathrm{~s}$, and extension at $72^{\circ} \mathrm{C}$ for $1 \mathrm{~min}$ [26]. The cycle was repeated for 33 cycles, followed by a final extension at $72^{\circ} \mathrm{C}$ for $10 \mathrm{~min}$. PCR products were purified using the Wizard Gel and PCR Clean-up System (Promega, Madison, WI, USA). Purified PCR products ( $\geq 50 \mathrm{ng} \cdot \mu \mathrm{L}^{-1}$ ) were subjected to direct sequencing by Macrogen (Tokyo, Japan), using the primer set described above. Raw sequence results were edited using MEGA version 6-software [27] to create 16S sequence fragments.

For homology searches, sequences were compared with the DNA Data Bank of Japan (DDBJ) using the Basic Local Alignment Search Tool (BLAST) program [28]. To construct the phylogenetic tree, sequences of type strains and closely related strains of Bradyrhizobium genospecies were retrieved from the BLAST database. All selected sequences including type strains and closet strains were aligned using the CLUSTALW function of the MEGA version 6-software [27]. After alignment, a phylogenetic tree was constructed according to the neighbor-joining method [29]. The phylogenetic tree was bootstrapped with 1000 replications of each sequence to evaluate the tree topology for reliability. Genetic distances were calculated using the Kimura two-parameter model [30].

\subsection{Nucleotide Sequence Accession Numbers}

The nucleotide sequences of 16S rRNA genes of 40 Bradyrhizobium strains were deposited in the DDBJ under the set of accession numbers LC515811 to LC515850.

\subsection{Myanmar Black Gram (Vigna mungo L.) Cultivars and Bradyrhizobium Strains}

Myanmar black gram (Vigna mungo L.) cultivars, Yezin-4 and Yezin-7 were collected from Food Legumes Section, Department of Agricultural Research, Ye- 
zin, Myanmar. The black gram Yezin-7 variety was the most widely grown cultivar in Myanmar and used for screening of the 40 indigenous Bradyrhizobium strains. For effectiveness of selected Bradyrhizboium strains, Black gram Yezin-4 and Yezin-7 cultivars from Myanmar were investigated. The purified forty Bradyrhizobium strains were cultured in A1E liquid media [31] on a rotary shaker $(100 \mathrm{rpm})$ at $30^{\circ} \mathrm{C}$ for 7 days. The cultures were diluted with sterilized $\mathrm{N}$-free half-strength modified Hoagland nutrient (MHN) solution [32] to ca $10^{7}$ cells $\mathrm{mL}^{-1}$ for Bradyrhizobium strains.

\subsection{Screening of Effective Bradyrhizobial Strains by Myanmar Black Gram Yezin-4 for Nitrogen Fixation}

The purified forty indigenous bradyrhizobial strains were screened for nitrogen fixing effectiveness on Myanmar black gram Yezin-7 in pots with vermiculite and MHN solution were covered with aluminum foil and autoclaved at $121^{\circ} \mathrm{C}$ for 20 min. Black gram Yezin-7 seeds were surface sterilized [33] and germinated on sterile petri dishes with filter paper. The germinated seeds were sown into the sterilized pot with vermiculite. In the non-inoculated treatment, a control treatment was also provided. The weights of original pots were measured. The plants were cultivated in incubator $\left(25^{\circ} \mathrm{C}\right.$ and $70 \%$ relative humidity). During the growing period, sterilized water was irrigated. The plants in each pot were uprooted and carefully washed with water so as not to detach the nodules. The acetylene reduction assay (ARA) was performed according to Haider et al., 1991 [34] to measure nitrogenase activity. The black gram plants were cut at the cotyledonary nodes. Then, the black gram roots with intact nodules were placed in a $100 \mathrm{~mL}$ conical flask and sealed with a serum stopper. A $12 \mathrm{~mL}$ aliquot of acetylene $\left(\mathrm{C}_{2} \mathrm{H}_{2}\right)$ gas was injected into the flask to replace the air with acetylene. The flasks containing roots with intact nodules were incubated at room temperature and $1.0 \mathrm{~mL}$ subsamples were analyzed at 5 and $65 \mathrm{~min}$, respectively. The ARA value, in terms of ethylene $\left(\mathrm{C}_{2} \mathrm{H}_{4}\right)$ production per plant, was measured using a flame ionization gas chromatograph (GC-14A, Shimadzu, Kyoto, Japan) equipped with a stainless steel column ( $3 \mathrm{~mm}$ diameter, $0.5 \mathrm{~m}$ length). The column was filled with Porapak R 60 - 80 mesh (Nicalai Tesque, Inc., Kyoto Japan). Column, injection and detection temperatures were $35^{\circ} \mathrm{C}, 45^{\circ} \mathrm{C}$ and $170^{\circ} \mathrm{C}$, respectively. $\mathrm{N}_{2}$ gas was used as the carrier gas at a flow rate of $45 \mathrm{~mL} \cdot \mathrm{min}^{-1}$. The number of nodules was counted after the assay. Shoots, roots and nodules were collected separately and oven dried for at $70^{\circ} \mathrm{C}$ for 48 hours to record the dry weight determination.

\subsection{Evaluation the Effectiveness of Selected Bradyrhizboium Strains on Two Myanmar Black Gram Cultivars: Yezin-4 and Yezin-7}

The five Bradyrhizobium strains of B. elkanii HpaBG5, B. liaoningense HpaBG6, B. liaoningense HpaBG7, B. liaoningense HpaBG12, B. elkanii LauBG38 (Table 3) were selected based on the results of the above screening experiment in their 
Table 3. The morphological characteristics of black gram bradyrhizobial isolate from Myanmar.

\begin{tabular}{|c|c|c|c|c|}
\hline Isolates & Genus and species & Dendrogram cluster & Shape & Size $(\mathrm{mm})$ \\
\hline HpaBG1 & Bradyrhizobium elkanii & Be1 & UF & 1.5 \\
\hline HpaBG2 & Bradyrhizobium elkanii & Be1 & UF & 1.5 \\
\hline HpaBG3 & Bradyrhizobium elkanii & Be1 & UF & 1.5 \\
\hline HpaBG4 & Bradyrhizobium sp. & Bs1 & UF & 1.5 \\
\hline HpaBG5 & Bradyrhizobium elkanii & Be1 & UF & 1.5 \\
\hline ChaBG6 & Bradyrhizobium liaoningense & Bl1 & $\mathrm{EP}$ & 1.5 \\
\hline ChaBG7 & Bradyrhizobium liaoningense & $\mathrm{Bl} 2$ & EP & 1.5 \\
\hline ChaBG8 & Bradyrhizobium liaoningense & Bl1 & EP & 1.5 \\
\hline ChaBG9 & Bradyrhizobium japonicum & Bo1 & $\mathrm{EP}$ & 1.5 \\
\hline ChaBG10 & Bradyrhizobium liaoningense & $\mathrm{Bl} 1$ & EP & 1.5 \\
\hline NyaBG11 & Bradyrhizobium liaoningense & $\mathrm{Bl} 1$ & EP & 1.5 \\
\hline NyaBG12 & Bradyrhizobium liaoningense & Bl1 & EP & 1.5 \\
\hline NyaBG13 & Bradyrhizobium liaoningense & $\mathrm{Bl} 1$ & EP & 1.5 \\
\hline NyaBG14 & Bradyrhizobium liaoningense & Bl1 & EP & 1.5 \\
\hline NyaBG15 & Bradyrhizobium liaoningense & $\mathrm{Bl} 1$ & EP & 1.5 \\
\hline DanBG16 & Bradyrhizobium liaoningense & $\mathrm{Bl} 2$ & $\mathrm{EP}$ & 2.0 \\
\hline DanBG17 & Bradyrhizobium japonicum & Bo1 & EP & 2.0 \\
\hline DanBG18 & Bradyrhizobium japonicum & Bo1 & EP & 2.0 \\
\hline DanBG19 & Bradyrhizobium japonicum & Bo1 & $\mathrm{EP}$ & 2.0 \\
\hline DanBG20 & Bradyrhizobium japonicum & Bol & EP & 2.0 \\
\hline SalBG21 & Bradyrhizobium sp. & Bs2 & UF & 1.5 \\
\hline SalBG22 & Bradyrhizobium yunamingense & Byl & UF & 1.5 \\
\hline SalBG23 & Bradyrhizobium sp. & Bs2 & UF & 1.5 \\
\hline SalBG24 & Bradyrhizobium sp. & Bs2 & UF & 1.5 \\
\hline SalBG25 & Bradyrhizobium sp. & Bs2 & UF & 1.5 \\
\hline SitBG26 & Bradyrhizobium liaoningense & $\mathrm{Bl} 2$ & EP & 1.5 \\
\hline SitBG27 & Bradyrhizobium liaoningense & $\mathrm{Bl} 2$ & $\mathrm{EP}$ & 1.5 \\
\hline SitBG28 & Bradyrhizobium liaoningense & $\mathrm{Bl} 1$ & EP & 1.5 \\
\hline SitBG29 & Bradyrhizobium japonicum & Bol & $\mathrm{EP}$ & 1.5 \\
\hline SitBG30 & Bradyrhizobium liaoningense & $\mathrm{Bl} 2$ & EP & 1.5 \\
\hline PyiBG31 & Bradyrhizobium japonicum & Bo1 & EP & 2.0 \\
\hline PyiBG32 & Bradyrhizobium japonicum & Bol & EP & 2.0 \\
\hline PyiBG33 & Bradyrhizobium japonicum & Bo1 & EP & 2.0 \\
\hline PyiBG34 & Bradyrhizobium sp. & Bs2 & $\mathrm{EP}$ & 2.0 \\
\hline PyiBG35 & Bradyrhizobium japonicum & Bol & EP & 2.0 \\
\hline LauBG36 & Bradyrhizobium elkanii & Be1 & UF & 1.5 \\
\hline LauBG37 & Bradyrhizobium elkanii & Be1 & UF & 1.5 \\
\hline LauBG38 & Bradyrhizobium elkanii & Be1 & UF & 1.5 \\
\hline LauBG39 & Bradyrhizobium liaoningense & $\mathrm{Bl} 2$ & UF & 1.5 \\
\hline LauBG40 & Bradyrhizobium elkanii & Be1 & UF & 1.5 \\
\hline
\end{tabular}


potential efficiency on ARA per plant. The experiment was performed in completely randomized design with three replicates. The inoculation and growing condition of pot experiment were also conducted as the above experiment. ARA per plant, nodule, root and shoot dry weight were determined after four weeks. Data were analyzed using the STATISTIX 8 software (Analytical Software, Tallahassee, FL, USA), and treatment means were compared by Tukey's HSD test $(\mathrm{P}<0.05)$ for the collected parameters.

\section{Results}

\subsection{Diversity of Indigenous Bradyrhizobium Strains for Myanmar Black Gram (Vigna mungo L.) Cultivars}

The forty root nodule bacteria were isolated from eight different soil samples from major black gram growing areas in Myanmar (Table 1, Table 2 and Figure 1). According to Somasegaran and Hoben, 1994 [25], these strains were proved as pure Bradyrhizobium strains. In YMA plates, the bradyrhizobial colonies reached $1-3 \mathrm{~mm}$ diameter with undulated pulvinate and entirely pulvinate shapes after 5 - 7 days incubation (Table 3).

Neighbor-joining trees for each gene had similar overall tree topologies. Groups were selected on the basis of the minimum standard changes between named species in the 16S rRNA phylogram (Figure 2), and all groups were well supported in neighbor-joining analyses which had less than $50 \%$ bootstrap support in the neighbor-joining tree. The results of the phylogenetic analysis based on the $16 \mathrm{~S}$ rRNA sequence, indicated that all the 40 isolates belonged to the genus Bradyrhizobium (Table 3 and Figure 2).

The seven clusters were identified in the phylogenetic tree including four clusters of $B$. liaoningense (Bl1 and $\mathrm{Bl} 2$ ), two clusters of $B$. sp. (Bs1 and $\mathrm{Bs} 2$ ), one cluster of each B. japonicum (Bj1), B. yunamingense (By1) and B. elkanii (Be1) (Figure 2). Among these clusters, two clusters of Bl1 and Bl2 were $98 \%$ sequence similarity with $B$. liaoningense CCNWSX $0360^{\mathrm{T}}$ and $B$. liaoningense LMG $18230^{\mathrm{T}}$ while two clusters of $\mathrm{Bs} 1$ and $\mathrm{Bs} 2$ were $98 \%$ sequence similar to $B$. sp. CI $110^{\mathrm{T}}$ and $B$. sp. JNVU DC11 ${ }^{\mathrm{T}}$. Among the clusters belonged to $B$. japonicum, $\mathrm{Bj} 1$ was showing $97 \%$ sequence similarity with $B$. japonicum LMG $6138^{\mathrm{T}}, B$. japonicum $\mathrm{N} 2225^{\mathrm{T}}$ B. japonicum CCBAU $83623^{\mathrm{T}}$ and $B$. japonicum $\mathrm{R} 33^{\mathrm{T}}$. The last two clusters of Byl and Bel groups were related to $B$. yunamingense $65010^{\mathrm{T}}$ and $B$. elkanii Cte $503^{\mathrm{T}}$ with at least $96 \%$ and $98 \%$ sequence similarity.

Almost all the collected isolates from Nyaunglebin Bago Region, Chaungzon Mon State and Sittwe Rakhine State black gram growing regions were identified as B. liaoningense. At Danubyu Ayeyarwady Region and Pyinmanar Nay Pyi Taw Region, most of the strains were identified as B. japonicum. On the other hand, more or less all the isolates from Launglon Tanintharyi Region and Hpa-an Kayin State were related to B. elkanii. However, all B. sp. strains were found in Salingyi Sagaing Region black gram growing region (Table 3 and Figure 2). 


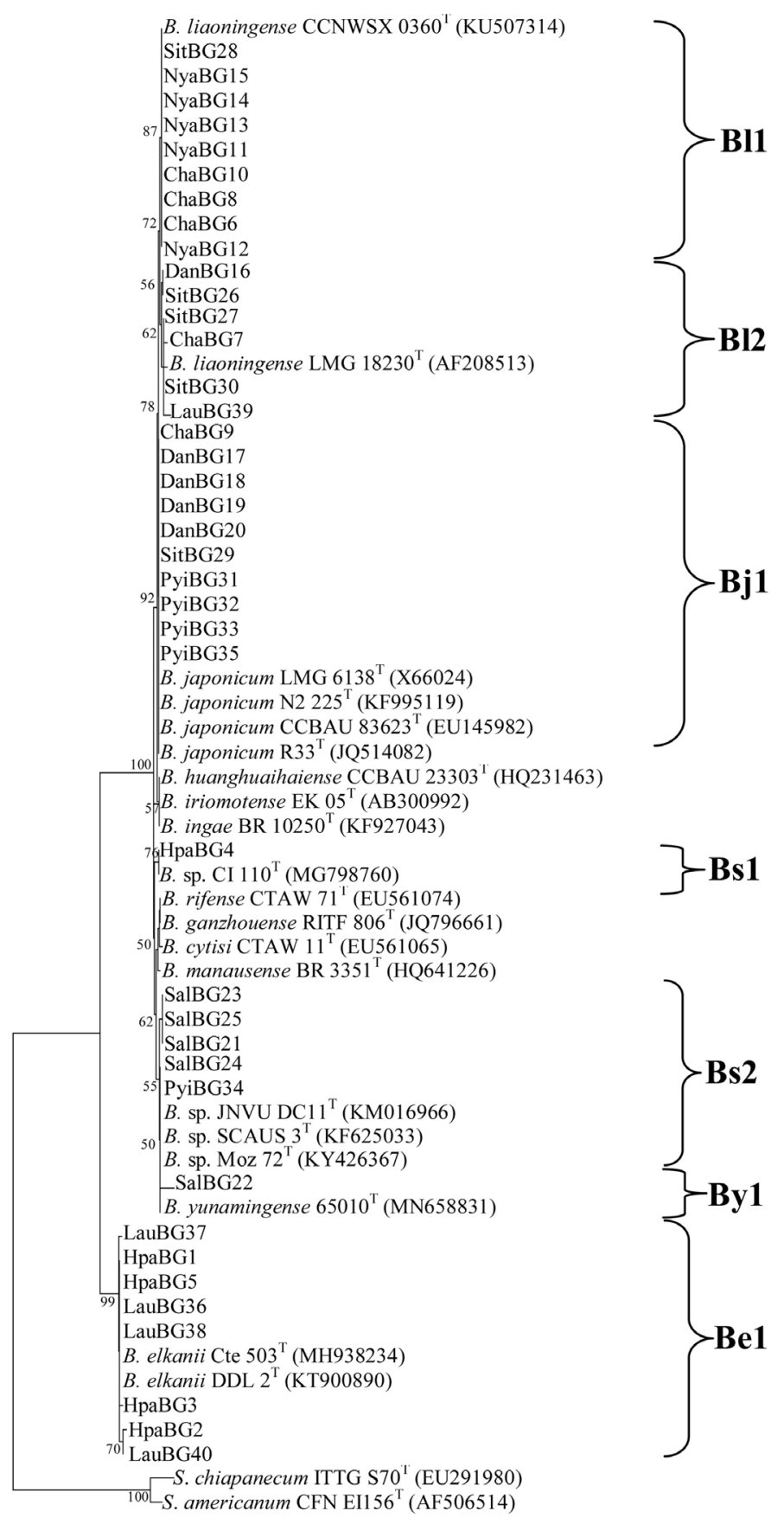

Figure 2. Position of the 40 strains in the phylogenetic tree based on the $16 \mathrm{~S}$ rRNA sequences of related Bradyrhizobium strains (in italics) retrieved from GenBank. The tree was constructed by the neighbor-joining method with the Kimura 2-parameter (K2P) distance correlation model and 1000 bootstrap replications. Bootstrap values above $50 \%$ are indicated at the nodes. Bar, $0.02 \mathrm{~K}_{\text {nuc }}$ in nucleotide sequences. Accession numbers of the reference strains, including all type strains of Bradyrhizobium, are shown in parentheses. B: Bradyrhizobium and $S$ : Sinorhizobium. The clustering of isolates and their distribution throughout the total studied area is noted into the tree: $\mathrm{Bl}=$ Bradyrhizobium liaoningense cluster 1; $\mathrm{Bl} 2$ = Bradyrhizobium liaoningense cluster 2; Bj1 = Bradyrhizobium japonicum cluster 1; Bs1 = Bradyrhizobium sp. cluster 1; Bs2 = Bradyrhizobium sp. cluster 2; By1 = Bradyrhizobium yunamingense cluster 1; Be1 = Bradyrhizobium elkanii cluster 1 . 
In this study, cluster Bl1 and Bl2 were observed in major black gram growing areas Nyaunglebin Bago Regio, Chaungzon Mon State, Sittwe Rakhine State, Danubyu Ayeyarwady Region and Launglon Tanintharyi Region. In Hpa-an Kayin State, Salingyi Sagaing Region and Pyinmanar Nay Pyi Taw Region, cluster Bs1 and Bs1 were found but in Chaungzon Mon State, Danubyu Ayeyarwady Region, Sittwe Rakhine State and Pyinmanar Nay Pyi Taw Region, cluster Bj1 was distributed. However, Byl cluster was only distributed in Salingyi Sagaing Region and Bel cluster was scattered in both Hpa-an Kayin State and Launglon Tanintharyi Region of black growing areas of Myanmar (Figure 2).

\subsection{Screening of Effective Bacterial Strains by Yezin-7 for Nitrogen Fixation}

In the screening experiment, the effective strains were determined their potential ability in the $\mathrm{N}$ fixation analyzed by means of ARA per plant. Each bacterial strain that responded on black gram Yezin-7 was expressed in Figure 3. The higher ARA per plant was found in plants inoculated by $B$. elkanii HpaBG5, $B$. liaoningense ChaBG6, B. liaoningense ChaBG7 and B. elkanii LauBG38 (Figure 3). From this experiment, five indigenous Bradyrhizibium strains were screened out for further studies based on their effectiveness in ARA per plant. There were four Bradyrhizobial strains from the highest ARA per plant value of $B$. elkanii HpaBG5, B. liaoningense ChaBG6, B. liaoningense ChaBG7, B. elkanii LauBG38 and one strain from the middle ARA per plant value of $B$. liaoningense NyaBG12.

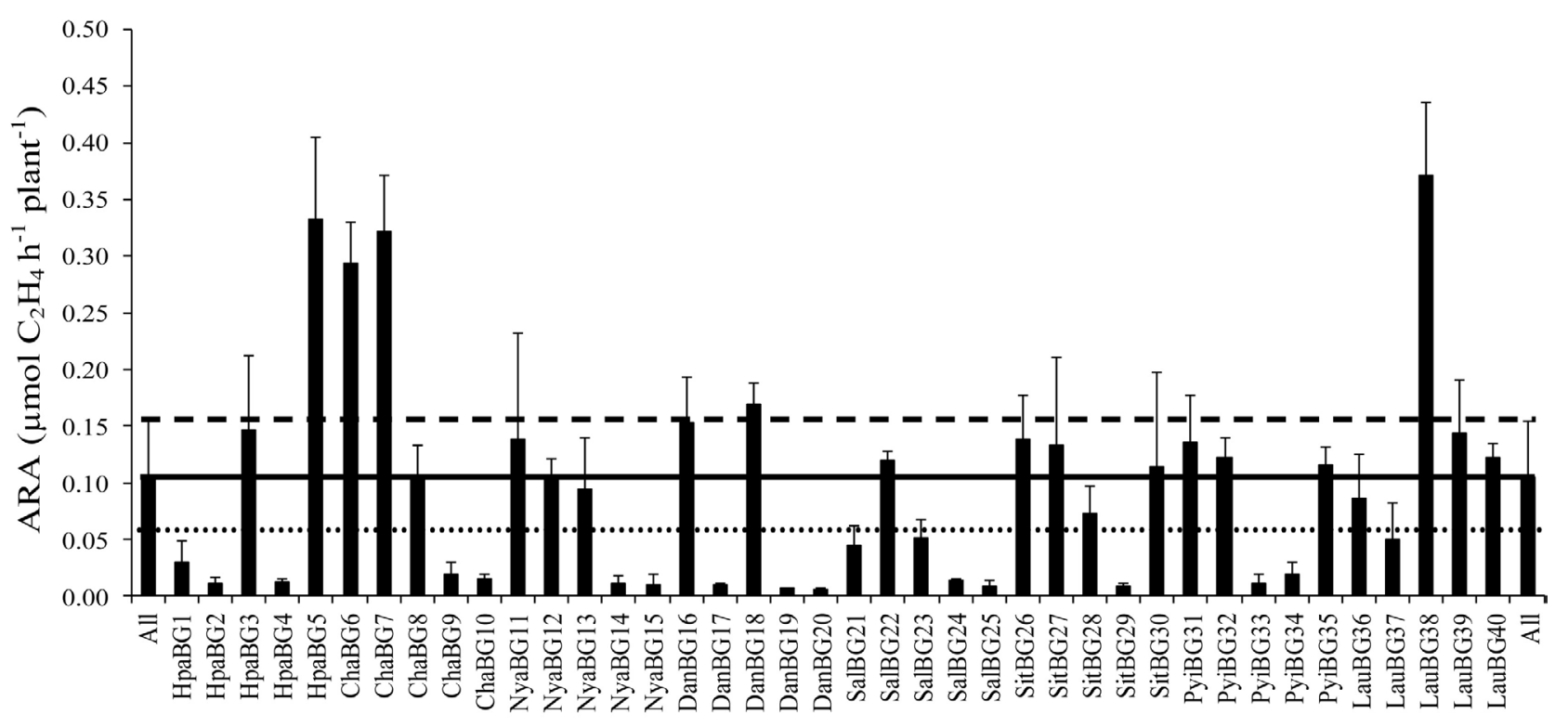

Bradyrhizobial strains

Figure 3. Acetylene reduction activity per plant of Yezin-7 Black gram (Vigna mungo) variety inoculated with 40 purified Bradyrhizobium strains after four weeks, Bars mean standard deviation levels. The middle line indicates average acetylene reduction activity per plant of all strains; the upper line means the higher acetylene reduction activity per plant and the lower line refers the lower acetylene reduction activity per plant of all strain. 


\subsection{Effectivity of Selected Bradyrhizobium Strains on Yezin-4 and Yezin-7 of Two Myanmar Black Gram Varieties}

Table 4 shows the effectiveness of selected Bradyrhizobial strains on ARA per plant, nodule and shoot dry weight of Yezin-4 and Yezin-7 black gram varieties. The ARA per plant of selected five Bradyrhizobial strains was significant affected on Yezin-4 and Yezin-7 black gram varieties (Table 4). It was found that significant higher in ARA per plant $(P<0.05)$ was observed by $B$. elkanii LauBG38 than $B$. liaoningense NyaBG12 in both Yezin-4 and Yezin-7 black gram varieties. In Yezin-4 black gram variety, the $B$. elkanii LauBG38 was insignificant differences that compared with B. elkanii HpaBG5, B. liaoningense ChaBG6 and B. liaoningense ChaBG7 in ARA per plant in Table 4.

On the other hand, the B. elkanii LauBG38 showed the highest nodule and shoot dry weights of $9.17 \mathrm{mg}$ plant ${ }^{-1}, 0.17 \mathrm{~g} \mathrm{plant}^{-1}$ in Yezin-4 and $10.97 \mathrm{mg}$ plant $^{-1}, 0.18$ g plant $^{-1}$ in Yezin-7 black gram variety, respectively. In Yezin-4 variety, inoculation with $B$. elkanii LauBG38 gave significant higher in nodule dry weight than B. liaoningense ChaBG6, B. liaoningense ChaBG7, and B. liaoningense NyaBG12. In Yezin-7 variety, B. elkanii LauBG38 gave the highest nodule dry weight among the tested strains and this strain was significant difference from those given by $B$. liaoningense ChaBG6 and B. liaoningense NyaBG12 (Table 4). However, shoot dry weight of tested B. elkanii LauBG38 was only significant difference than B. liaoningense NyaBG12 in both Myanmar black gram varieties (Table 4).

\section{Discussion}

The symbiotic association between legumes and rhizobia is one of the most important contributors to the world's supply of biologically fixed nitrogen to agriculture. Effective symbiosis can only be achieved when the nodules are formed

Table 4. Response of selected Myanmar bradyrhizobial strains on acetylene reduction activity, nodule and shoot dry weight of Yezin-4 and Yezin-7 black gram varieties after four weeks.

\begin{tabular}{|c|c|c|c|c|c|c|}
\hline \multirow[b]{2}{*}{ Treatment } & \multicolumn{3}{|c|}{ Yezin-4 } & \multicolumn{3}{|c|}{ Yezin-7 } \\
\hline & $\begin{array}{c}\text { NDW } \\
\left(\mathrm{mg} \cdot \text { plant }^{-1}\right)\end{array}$ & $\begin{array}{c}\text { SDW } \\
\left(\mathrm{g} \cdot \text { plant }^{-1}\right)\end{array}$ & $\begin{array}{c}\text { ARA } \\
\left(\mu \text { mole }_{2} \mathrm{H}_{4}\right. \\
\left.\mathrm{h}^{-1} \text {. } \text { plant }^{-1}\right)\end{array}$ & $\begin{array}{c}\text { NDW } \\
\left(\text { mg.plant }{ }^{-1}\right)\end{array}$ & $\begin{array}{c}\text { SDW } \\
\left(\mathrm{g} \cdot \text { plant }^{-1}\right)\end{array}$ & $\begin{array}{c}\text { ARA } \\
\left(\mu \text { mole }_{2} \mathrm{H}_{4}\right. \\
\left.\mathrm{h}^{-1} \text { plant }^{-1}\right)\end{array}$ \\
\hline HpaBG5 & $6.83 \mathrm{ab}$ & $0.15 \mathrm{ab}$ & $0.19 \mathrm{ab}$ & $7.83 \mathrm{ab}$ & $0.17 \mathrm{ab}$ & $0.23 \mathrm{ab}$ \\
\hline ChaBG6 & $5.50 \mathrm{~b}$ & $0.14 \mathrm{ab}$ & $0.17 \mathrm{ab}$ & $5.93 \mathrm{~b}$ & $0.15 \mathrm{ab}$ & $0.15 \mathrm{~b}$ \\
\hline ChaBG7 & $5.77 \mathrm{~b}$ & $0.14 \mathrm{ab}$ & $0.18 \mathrm{ab}$ & $7.30 \mathrm{ab}$ & $0.16 \mathrm{ab}$ & $0.22 \mathrm{ab}$ \\
\hline NyaBg12 & $4.63 \mathrm{~b}$ & $0.11 \mathrm{~b}$ & $0.10 \mathrm{~b}$ & $4.80 \mathrm{~b}$ & $0.12 \mathrm{~b}$ & $0.12 \mathrm{~b}$ \\
\hline LauBG38 & $9.17 \mathrm{a}$ & $0.17 \mathrm{a}$ & $0.36 \mathrm{a}$ & $10.97 \mathrm{a}$ & $0.18 \mathrm{a}$ & $0.41 \mathrm{a}$ \\
\hline
\end{tabular}

Means in each column followed by different letters differed significantly at $P<0.05$ (Tukey's test), NDW, SDW means nodule and shoot dry weight per plant and ARA means $\mathrm{C}_{2} \mathrm{H}_{4}$ produced per hour per plant, NDW and ARA of non-inoculated treatment is zero for both black gram varieties, SDW of non-inoculated treatment is $0.05 \mathrm{~g} \mathrm{plant}^{-1}$ for both back gram varieties. 
by effective rhizobia. The symbiotic relationship between rhizobia and black gram has not been extensively analyzed. Therefore, this is the first report investigation of addressing the genetic diversity and evaluation the effectiveness of indigenous Bradyrhizobium strains for Myanmar black gram cultivars.

Sequence analysis of $16 \mathrm{~S}$ ribosomal RNA (rRNA) has been developed used as one of the most important methods in taxonomy and phylogenic analysis of bacteria [35] [36] [37] [38]. The phylogenetic investigates based on 16S rRNA gene sequences showed that the rhizobial strains nodulating black gram in India were dispersed under the genus Bradyrhizobium [39]. These results were dependable with former reports that showed black gram rhizobia were more closely associated with Bradyrhizobium species [39] [40] [41]. The present study was focused on investigation of $16 \mathrm{~S}$ rRNA region of 40 Bradyrhizobial strains that were successfully isolated from the different soil samples of major black gram growing areas in Myanmar and proved as pure Bradyrhizobium strains [25].

The genus Bradyrhizobium was proposed by Jordan (1982) [42] for the slowgrowing root nodule bacteria on yeast extract-mannitol agar (YMA) medium. The Bradyrhizobium genus contained 12 defined species: Bradyrhizobium japonicum [42], B. elkanii [43], B. liaoningense [44], B. yuanmingense [45], B. betae [46], B. canariense [47], B. denitrificans [48], B. iriomotense [49], B. jicamae, $B$. pachyrhizi [50], B. lablabi [51] and B. cytisi [52]. With the exception of B. betae, all species are symbiotic nitrogen fixing bacteria associated with different legumes.

Previously, Soe et al., 2013 [52] and Htwe et al., 2015 [53] confirmed that the collected rood nodule bacteria isolates from different soybean growing of Myanmar were categorized and identified as the B. japonicum, B. elkanii, $B$. yuanmingense and Bradyrhizobium sp. and B. liaoningense from Myanmar soybean growing areas. Several scientists found the B. japonicum, B. elkanii, $B$. liaoningense and $B$. yuanmingense [54] [55] [56] [57] have been isolated from root nodules of soybean grown in different regions of China as well. Clear biogeographic patterns have been revealed in the soybean rhizobia and soil types appeared to be the main factor of the biogeography of these bacteria [58]. Cowpea bradyrhizobia isolated in Africa [59], in China [60], and in Brazil [61] were identified as B. elkanii, B. japonicum, B. liaoningense, B. yuanmingense or as novel Bradyrhizobium lineages. Less information is available for indigenous rhizobia nodulating green gram and black gram. Also, unidentified slow growers with different 16S rRNA gene haplotypes were isolated from black gram plants growing in the south of India [62], while some strains isolated from green gram and black gram plants growing in Thailand were closely related to $B$. japonicum [63]. In our present investigation, $B$. liaoningense, $B$. japonicum, $B$. sp., $B$. yunamingense and $B$. elkanii were collected from major black gram growing areas of Myanmar with different locations, weathers and soil conditions.

The agro-ecological origin of rhizobial inoculants and thus most possibly edaphic and climatic variation are often not considered sufficiently to make in- 
oculation successful. A variety of biotic and abiotic factors, such as host plant, cultivation history, drought, soil $\mathrm{pH}$, salinity, mineral nutrient availability, soil organic carbon content and texture, are known to affect rhizobial diversity and distribution [64]. This is evidence that the collected 40 Bradyrhizobia isolates from major black gram growing areas of Myanmar with various soil types, soil $\mathrm{pH}$ and soil nutrients were affected to bradyrhizobial strains diversity and distribution.

A phylogenetic analysis of present study showed that indigenous $B$. liaoningense as a dominant strain was distributed throughout the five major black gram growing areas of Myanmar with a $\mathrm{pH}$ range of $4.69-6.70$. B. liaoningense strain was isolated from soybean growing areas in China [44] and in Myanmar [53].

Symbiotic $\mathrm{N}_{2}$ fixation can recompense for absent soil nitrogen $(\mathrm{N})$ and thus potentially save costly mineral $\mathrm{N}$ fertilizer [65]. Rhizobial inocula for inoculating legumes increasingly account for differences in symbiotic specificity and effectivity, two parameters that are often correlated [66]. Several studies also reported significant increase growth parameters and yield due to the inoculation of rhizobial isolates in chickpea in Myanmar [14], green gram and black gram in Thailand [67]. In addition, indigenous rhizobial strains also play important role since they have adapted to local environmental conditions.

An effective Rhizobium-legume symbiosis largely depends on the presence of a specific and compatible strain in the soil for a particular legume. Several studies have reported a significant increase in green gram and black gram growth parameters and yield due to the inoculation of bradyrhizobial isolates [68]. In the present study, the effectiveness of indigenous 40 Bradyrhizobium strains in symbiosis association with Yezin-7 Myanmar black gram variety by using sterilized vermiculite with MHN as a growth media. When the nitrogen fixation in terms of ARA per plant with the test Bradyrhizobium strains was compared, four Bradyrhizobium strains designated as B. elkanii HpaBG5, B. liaoningense ChaBG6, B. liaoningense ChaBG7 and B. elkanii LauBG38 were found to be more effective than other tested strains. The effectiveness of a strain of rhizobia is due to the genetic interaction with the host plant, which is known as host-strain specificity. Thus, the selection of strains of rhizobia for cultivated legume varieties is a critical step in the production of the legume inoculants [69].

In this study, the evaluation the effectiveness of selected Bradyrhizboium strains on two Myanmar black gram varieties, Yezin-4 and Yezin-7 were investigated. It was observed that the inoculation of Bradyrhizobium elkanii LauBG38 gave significantly higher in ARA per plant for nitrogen fixation and nodule dry weight in both black gram varieties. ARA per plant for nitrogen fixation and nodule dry weight of Yezin-7 variety was higher than those of Yeizn-4 black gram. Therefore based on the results of nodulation efficiency of nodule dry weight of the plants Yezin-7 could be used in future experiment as superior host genotypes for high nitrogen fixation. Symbiotic nitrogen fixation depends on interactions among the genotype of the host plant, rhizobial strain genotype and 
environment. In grain legume species, genotypic variability affected nodule number or mass or nitrogenase activity [70] pointed out that, through the use of plant genotypes in symbiotic ability, it is possible to identify genes responsible for a particular part of the process, depending on a particular rhizobial strain used. The selection of effective rhizobial strains for cultivated legumes is a critical step in the production of high quality legume inoculant.

The effectiveness of indigenous Bradyrhizobium strains was observed in Myanmar back gram cultivars using the correct varieties, and proper nodulated bacteria. This is the first report of phylogenetic diversity and evaluation the effectiveness of indigenous Bradyrhizobium strains for Myanmar black gram cultivars. The selected Bradyrhizobium elkanii LauBG38 strain might be considered for rhizobial inoculatns to use as Biofertilizer in Myanmar near future.

\section{Conclusion}

This is the first report on describing Bradyrhizobium strains that were isolated from soil samples of major black gram growing areas of Myanmar and the effectiveness of those strains for plant growth and nitrogen fixation of Myanmar Black gram varieties. In total, 40 indigenous bradyrhizobia were successfully isolated and their geographic distribution was determined based on the analysis of the $16 \mathrm{~S}$ rRNA region. Our results indicated that $B$. liaoningense strain was widely distributed in the major black gram growing regions of Myanmar whereas B. japonicum was found more abundant in Danubyu Ayeyarwady Region and Pyinmanar Nay Pyi Taw Region. However, B. elkanii weas found more abundant in Launglon Tanintharyi Region and Hpa-an Kayin State. The effectiveness of those strains for plant growth and nitrogen fixation of Myanmar black gram varieties was investigated in the present study. The 40 Bradyrhizobium strains were screened for their effectiveness on Yezin-7 black gram variety and five Bradyrhizobium strains were selected. These selected strains were tested for their effectiveness on Yezin-4 and Yezin-7 black gram varieties. The Bradyrhizobium elkanii LauBG38 was significantly superior in both black gram varieties. All of these experiments were conducted under the control conditions by growing the plants in the sterilized vermiculite with MHN solution. So, the bradyrhizobial strains selected in the control room trials then must be evaluated in the field. Although it is a preliminary study, it can help for the future study in the inoculants production. The further investigation of symbiotic effectiveness of selected indigenous bradyrhizobia strains on Myanmar black gram cultivars will be examined in the field condition. We do hope that Myanmar Bradyrhizobium strains will be able to use as Biofertilizer for black gram cultivars that enhance crop production through nitrogen fixation and yield.

\section{Acknowledgements}

The authors are thankful to Japan Society for the Promotion of Science (JP19F18079) for their financial support of the present study. We are also very grateful 
to the members of Land Use Division, Department of Agriculture and members of Department of Agricultural Research, Ministry of Agriculture, Livestock and Irrigation, Myanmar who helped for collecting soil samples and black gram seeds for these experiments.

\section{Conflicts of Interest}

The authors declare no conflicts of interest regarding the publication of this paper.

\section{References}

[1] Nedumaran, S., Abinaya, P., Jyosthnaa, P., Shraavya, B., Rao, P. and Bantilan, C. (2015) Grain Legumes Production, Consumption and Trade Trends in Developing Countries. Working Paper Series No. 60. ICRISAT Research Program, Telangana, India. http://oar.icrisat.org/8991

[2] Jat, B.L., Choudhary. P., Singh, G. and Reddy, G.L. (2017) Effect of Bio-Fertilizer on Different Varieties of Black Gram (Vigna mungo L.). International Journal of Current Microbiology and Applied Sciences, 6, 302-316.

https://doi.org/10.20546/ijcmas.2017.602.036

[3] Somta, P., Chen, J., Yundaeng, C., Yuan, X., Yimram, T., Tomooka N. and Chen, X. (2019) Development of an SNP-Based High-Density Linkage Map and QTL Analysis for Bruchid (Callosobruchus maculatus F.) Resistance in Black Gram (Vigna mungo (L.) Hepper). Scientific Reports, 9, 3930.

https://doi.org/10.1038/s41598-019-40669-5

[4] Wai, P.P. (2019) Comparative Study of Profitability of Black Gram Production before and after India's Import Suspension in Kyauktaga Township, Bago Region (Ph.D. Thesis). Yezin Agriculture University, Myanmar, 118.

[5] Ministry of Agriculture, Livestock and Irrigation (2018) Myanmar Agriculture in Brief. Department of Planning, Nay Pyi Taw, Myanmar.

[6] Korir, H., Mungai, N.W., Thuita, M., Hamba Y. and Masso C. (2017) Co-inoculation Effect of Rhizobia and Plant Growth Promoting Rhizobacteria on Common Bean Growth in a Low Phosphorus Soil. Frontiers in Plant Science, 8, 141. https://doi.org/10.3389/fpls.2017.00141

[7] Boonkerd, N. and Singleton, P (2002) Production of Rhizobium Biofertilizer. In: Biotechnology of Biofertilizers, Narosa Publishing House, New Delhi, India, 122-128.

[8] Sessitsch, A., Howieson, J.G., Perret, X., Antoun, H. and Martínez-Romero, E. (2002) Advances in Rhizobium Research. Critical Reviews in Plant Sciences, 21, 323-378. https://doi.org/10.1080/0735-260291044278

[9] Than, M.M., San, K.K. and Thein, M.M. (2006) Evaluation of Effective Rhizobial Strains for Commercial Legume Inoculants. Journal of Agriculture, Forestry Livestock and Fishery Science, 6, 264-280.

[10] Than, M.M., Myint, H., Lwin, T. and Myint, Y.Y. (2003) Comparison of Nodulation Efficiency between Native Rhizobium Strains and Exotic TAL Strains on Green Gram (Vigna radiata). In: Proceedings of the 3 rd Agricultural Conference, Yezin Agriculture University, Yezin, Myanmar, 50-58.

[11] Brockwell, J., Dudman, W.F., Gibson, A.H., Hely, F.W. and Erbinsion, A.C. (1968) An Integrated Programme for the Improvement of Legume Inoculant Strains. Transactions 9 th International Congress Soil Science, 2, 103-114. 
[12] Date, R.A. (1970) Microbiological Problems in the Inoculation and Nodulation of Legumes. Plant and Soil Florida Proceedings, 34, 71-79. https://doi.org/10.1007/BF01372901

[13] Herridge, D., Maw, J.B., Thein, M.M., Rupela, O.P., Boonkerd, N., Thao, T.Y., Deaker, R., Hartley, E. and Gemell, G. (2008) Expanding Production and Use of Legume Inoculants in Myanmar and Vietnam. http://agronomyaustraliaproceedings.org

[14] Than, M.M. (2010) Evaluation and Selection of Root Nodule Bacteria (Mesorhizobium ciceri) and Chickpea Germplasm for High Nitrogen Fixation. Ph.D. Thesis, Yezin Agriculture University, Myanmar, 118.

[15] Aung, T.T. (2007) Selection of Effective Bradyrhizobium Strains for Soybean (Glycine max). Yezin Agriculture University, Myanmar, 38-41.

[16] Soe, K.M., Bhromsiri, A. and Karladee, D. (2010) Effect of Selected Endophytic actinomycetes (Steptomyces sp.) and Bradyrhizobia from Myanmar on Growth, Nodulation, Nitrogen Fixation and Yield of Different Soybean Varieties. Chiang Mai University Journal of Natural Sciences, 9, 95-109.

[17] Soe, K.M. and Yamakawa, T. (2013a) Low-Density Co-Inoculation of Myanmar Bradyrhizobium yuanmingense MAS34 and Streptomyces griseoflavus P4 to Enhance Symbiosis and Seed Yield in Soybean Varieties. American Journal of Plant Sciences, 4, 1879-1892. https://doi.org/10.4236/ajps.2013.49231

[18] Htwe, A.Z., Moh, S.M., Soe, K.M., Moe, K. and Yamakawa, T. (2019) Effects of Biofertilizer Produced from Bradyrhizobium and Streptomyces griseoflavus on Plant Growth, Nodulation, Nitrogen Fixation, Nutrient Uptake, and Seed Yield of Mung Bean, Cowpea, and Soybean. Agronomy, 9, 77. https://doi.org/10.3390/agronomy9020077

[19] Shein, H.A. (2015) The Soil Types and Characteristics of Myanmar. Department of Agriculture, Ministry of Agriculture, Livestocks and Irrigation, Nay Pyi Taw, Myanmar.

[20] Aung, L.L., Zin, E.E., Theingi, P., Elvera, N., Aung, P.P., Han, T.T., Oo, Y. and Skaland, R.G. (2017) Myanmar Climate Report. Department of Meteorology and Hydrology Myanmar, Ministry of Transport and Communications, Government of the Republic of the Union of Myanmar.

[21] Ohyama, T., Ito, M., Kobayashi, K., Araki, S., Yasuyoshi, S., Sasaki, O., Yamazaki, T., Soyama, K., Tanemura, R. and Mizuno, Y. (1991) Analytical Procedures of N, P, $\mathrm{K}$ Contents in Plant and Manure Materials Using $\mathrm{H}_{2} \mathrm{SO}_{4}-\mathrm{H}_{2} \mathrm{O}_{2}$ Kjeldahl Digestion method. Bulletin Faculty of Agriculture, Niigata University, Japan, 43, 110-120.

[22] Cataldo, D.A., Schrader, L.E. and Youngs, V.L. (1974) Analysis by Digestion and Colorimetric Assay of Total Nitrogen in Plant Tissues High in Nitrate. Crop Science, 14, 854-856. https://doi.org/10.2135/cropsci1974.0011183X001400060024x

[23] Murphy, J. and Riley, J. (1962) A Modified Single Solution Method for the Determination of Phosphate in Natural Waters. Analytica Chimica Acta, 27, 31-36. https://doi.org/10.1016/S0003-2670(00)88444-5

[24] Muramoto, J., Goto, I. and Ninaki, M. (1992) Rapid Analysis of Exchangeable Cations and Cation Exchange Capacity (CEC) of Soils by Shaking Extraction Method. Journal of Soil Science and Plant Nutrition, 63, 210-215.

[25] Somasegaran, P. and Hoben, H.J. (1994) Handbook for Rhizobia. In: Methods in Legume-Rhizobium Technology, Springer-Verlag, New York, 240-258. https://doi.org/10.1007/978-1-4613-8375-8

[26] Sarr, P.S., Yamakawa, T., Fujimoto, S., Saeki, Y., Thao, H.T.B. and Myint, A.K. 
(2009) Phylogenetic Diversity and Symbiotic Effectiveness of Root-Nodulating Bacteria Associated with Cowpea in the South-West Area of Japan. Microbes and Environments, 24, 285-292. https://doi.org/10.1264/jsme2.ME08558

[27] Tamura, K., Stecher, G., Peterson, D., Filipski, A. and Kumar, S. (2013) MEGA6: Molecular Evolutionary Genetics Analysis Version 6.0. Molecular Biology and Evolution, 30, 2725-2729. https://doi.org/10.1093/molbev/mst197

[28] Altschul, S.F., Madden, T.L., Schäffer, A.A., Zhang, J., Zhang, Z., Miller, W. and Lipman, D.J. (1997) Gapped BLAST and PSI-BLAST: A New Generation of Protein Database Search Programs. Nucleic Acids Research, 25, 3389-3402. https://doi.org/10.1093/nar/25.17.3389

[29] Saitou, N. and Nei, M. (1987) The Neighbor-Joining Method: A New Method for Reconstructing Phylogenetic Trees. Molecular Biology and Evolution, 4, 406-425.

[30] Kimura, M.A. (1980) Simple Method for Estimating Evolutionary Rates of Base Substitutions through Comparative Studies of Nucleotide Sequences. Journal of Molecular Evolution, 16, 111-120. https://doi.org/10.1007/BF01731581

[31] Kuykendall, L.D. (1979) Transfer of R Factors to and between Genetically Marked Sublines of Rhizobium japonicum. Applied and Environmental Microbiology, 37, 862-866. https://doi.org/10.1128/AEM.37.5.862-866.1979

[32] Tsurumaru, H., Yamakawa, T., Tanaka, M. and Sakai, M. (2008) Tn5 Mutants of Bradyrhizobium japonicum Is-1 with Altered Compatibility with Rj2-Soybean Cultivars. The Journal of Soil Science and Plant Nutrition, 54, 197-203. https://doi.org/10.1111/j.1747-0765.2007.00225.x

[33] Yamakawa, T., Shirai, T. and Ishizuka, J. (2000) Effects of Symbiosis with Rhizobium fredii on Transport of Fixed Nitrogen in the Xylem of Soybean Plant. The Journal of Soil Science and Plant Nutrition, 46, 885-892. https://doi.org/10.1080/00380768.2000.10409154

[34] Haider, J., Hussam, A.K.M.A., Ikeda, M., Yamakawa, T. and Ishizuka, J. (1991) Effects of Nitrate Application on Growth, Nodulation and Nitrogen Fixation of Nitrate-Tolerant Mutant Soybean. The Journal of Soil Science and Plant Nutrition, 37, 521-529. https://doi.org/10.1080/00380768.1991.10415065

[35] Weisburg, W.G., Barns, S.M., Pelletier, D.A. and Lane, D.J. (1991) 16S Ribosomal DNA Amplification for Phylogenetic Study. Journal of Bacteriology, 173, 697-703. https://doi.org/10.1128/JB.173.2.697-703.1991

[36] Chen, W.M., Zhu, W.F., Bontemps, C., Young, J.P.W. and Wei, G.H. (2010) Mesorhizobium alhagi sp. nov., Isolated from Wild Alhagi sparsifolia in North-Western China. International Journal of Systematic and Evolutionary Microbiology, 60, 958-962. https://doi.org/10.1099/ijs.0.014043-0

[37] Martens, M., Delaere, M., Coopman, R., De Vos, P., Gillis, M. and Willems, A. (2007) Multilocus Sequence Analysis of Ensifer and Related Taxa. International Journal of Systematic and Evolutionary Microbiology, 57, 489-503. https://doi.org/10.1099/ijs.0.64344-0

[38] Laranjo, M., Young, J.P.W. and Oliveira, S. (2012) Multilocus Sequence Analysis Reveals Multiple Symbiovars within Mesorhizobium Species. Systematic and Applied Microbiology, 35, 359-367. https://doi.org/10.1016/j.syapm.2012.06.002

[39] Saleena L.M., Loganathan, P., Rangarajan, S. and Nair, S. (2001) Genetic Diversity and Relationship between Bradyrhizobium Strains Isolated from Blackgram and Cowpea. Biol Fertil Soils, 34, 276-281. https://doi.org/10.1007/s003740100391

[40] Javaid, A., Bajwa, R. and Anjum, T. (2006) Response of Black Gram (Vigna mungo (L.) Hepper) to Bradyrhizobium japonicum Inoculation under Different Soil Amend- 
ment Systems. Pakistan Journal of Botany, 38, 851-857.

[41] Appunua C., N'Zoued, A., Moulind, L., Depret, G. and Laguerre, G. (2009) Vigna mungo, V. radiata and V. unguiculata Plants Sampled in Different AgronomicalEcological-Climatic Regions of India Are Nodulated by Bradyrhizobium yuanmingense. Systematic and Applied Microbiology, 32, 460-470. https://doi.org/10.1016/j.syapm.2009.05.005

[42] Jordan, D. C. (1982) Transfer of Rhizobium japonicum to Bradyrhizobium gen. nov., a Genus of Slow-Growing, Root Nodule Bacteria from Leguminous Plants. International Journal of Systematic and Evolutionary Microbiology, 32, 136-139. https://doi.org/10.1099/00207713-32-1-136

[43] Kuykendall, L.D., Saxena, B., Devine, T.E. and Udell, S.E. (1992) Genetic Diversity in Bradyrhizobium japonicum Jordan 1982 and a Proposal for Bradyrhizobium elkanii sp. nov. The Canadian Journal of Microbiology, 38, 501-505. https://doi.org/10.1139/m92-082

[44] Xu, L.M., Ge, C., Cui, Z., Li, J. and Fan, H. (1995) Bradyrhizobium liaoningense sp. nov., Isolated from the Root Nodules of Soybeans. International Journal of Systematic and Evolutionary Microbiology, 45, 706-711.

https://doi.org/10.1099/00207713-45-4-706

[45] Yao, Z.Y., Kan, F.L., Wang, E.T., Wei, G.H. and Chen, W.X. (2002) Characterization of Rhizobia that Nodulate Legume Species of the Genus Lespedeza and Description of Bradyrhizobium yuanmingense sp. nov. International Journal of Systematic and Evolutionary Microbiology, 52, 2219-2230. https://doi.org/10.1099/ijs.0.01408-0

[46] Rivas, R., Willems, A., Palomo, J.L., Garcı-Benavides, P., Mateos, P.F., MartınezMolina, E., Gillis, M. and Velazquez, E. (2004) Bradyrhizobium betae sp. nov., Isolated from Roots of Beta vulgaris Affected by Tumour-Like Deformations. International Journal of Systematic and Evolutionary Microbiology, 54, 1271-1275. https://doi.org/10.1099/ijs.0.02971-0

[47] Vinuesa, P., Leon-Barrios, M., Silva, C., Willems, A., Jarabo-Lorenzo, A., Perez-Galdona, R., Werner, D. and Martınez-Romero, E. (2005) Bradyrhizobium canariense sp. nov., an Acid-Tolerant Endosymbiont that Nodulates Genistoid Legumes (Papilionoideae: Genisteae) from the Canary Islands, along with Bradyrhizobium japonicum bv. Genistearum, Bradyrhizobium genospecies Alpha and Bradyrhizobium genospecies Beta. International Journal of Systematic and Evolutionary Microbiology, 55, 569-575. https://doi.org/10.1099/ijs.0.63292-0

[48] Van Berkum, P., Leibold, J.M. and Eardly, B.D. (2006) Proposal for Combining Bradyrhizobium spp. (Aeschynomene indica) with Blastobacter denitrificans and to Transfer Blastobacter denitrificans (Hirsch and Muller, 1985) to the Genus Bradyrhizobium as Bradyrhizobium denitrificans (comb. nov.). Systematic and Applied Microbiology, 29, 207-215. https://doi.org/10.1016/j.syapm.2005.07.014

[49] Islam, M.S., Kawasaki, H., Muramatsu, Y., Nakagawa, Y. and Seki, T. (2008) Bradyrhizobium iriomotense sp. nov., Isolated from a Tumorlike Root of the Legume Entada koshunensis from Iriomote Island in Japan. Bioscience, Biotechnology, and Biochemistry, 72, 1416-1429. https://doi.org/10.1271/bbb.70739

[50] Ramırez-Bahena, M.H., Peix, A., Rivas, R., Camacho, M., Rodrıguez-Navarro, D.N., Mateos, P.F., Martınez-Molina, E., Willems, A. and Velazquez, E. (2009) Bradyrhizobium pachyrhizi sp. nov. and Bradyrhizobium jicamae sp. nov., Isolated from Effective Nodules of Pachyrhizus erosus. International Journal of Systematic and Evolutionary Microbiology, 59, 1929-1934.

https://doi.org/10.1099/ijs.0.006320-0 
[51] Chang, Y.L., Wang, J.Y., Wang, E.T., Liu, H.C., Sui, X.H. and Chen, W.X. (2011) Bradyrhizobium lablabi sp. nov., Isolated from Effective Nodules of Lablab purpureus and Arachis hypogaea. International Journal of Systematic and Evolutionary Microbiology, 61, 2496-2502. https://doi.org/10.1099/ijs.0.027110-0

[52] Soe, K.M., Yamakawa, T., Hashimotoa, S. and Sarr, P.S. (2013) Phylogenetic Diversity of Indigenous Soya Bean Bradyrhizobia from Different Agro-Climatic Regions in Myanmar. Science Asia, 39, 574-583.

https://doi.org/10.2306/scienceasia1513-1874.2013.39.574

[53] Htwe, A.Z., Yamakawa, T., Sarr. P.S. and Sakata, T. (2015) Diversity and Distribution of Soybean-Nodulating Bradyrhizobia Isolated from Major Soybean-Growing Regions in Myanmar. African Journal of Microbiology Research, 9, 2183-2196.

http://www.academicjournals.org/AJMR https://doi.org/10.5897/AJMR2015.7702

[54] Han, L., Wang, E., Han, T., Liu, J., Sui, X., Chen, W. and Chen, W. (2009) Unique Community Structure and Biogeography of Soybean Rhizobia in the Saline-Alkaline Soils of Xinjiang, China. Plant \& Soil, 324, 291-305. https://doi.org/10.1007/s11104-009-9956-6

[55] Li, Q.Q., Wang, E.T., Zhang, Y.Z., Zhang, Y.M., Tian, C.F., Sui, X.H., Chen, W.F. and Chen, W.X. (2011) Diversity and Biogeography of Rhizobia Isolated from Root Nodules of Glycine max Grown in Hebei Province, China. Microbial Ecology, 61, 917-931. https://doi.org/10.1007/s00248-011-9820-0

[56] Man, C., Wang, H., Chen, W., Sui, X., Wang, E. and Chen, W. (2008) Diverse Rhizobia Associated with Soybean Grown in the Subtropical and Tropical Regions of China. Plant \& Soil, 310, 77-87. https://doi.org/10.1007/s11104-008-9631-3

[57] Wang, H., Man, C., Wang, E. and Chen, W. (2009) Diversity of Rhizobia and Interactions among the Host Legumes and Rhizobial Genotypes in an Agricultural-Forestry Ecosystem. Plant \& Soil, 314, 169-182. https://doi.org/10.1007/s11104-008-9716-Z

[58] Zhang, Y.M., Li Jr., Y., Chen, W.F., Wang, E.T., Tian, C.F., Li, Q.Q., Zhang, Y.Z., Sui, X.H. and Chen, W.X. (2011) Biodiversity and Biogeography of Rhizobia Associated with Soybean Plants Grown in the North China Plain. Applied and Environmental Microbiology, 77, 6331-6342. https://doi.org/10.1128/AEM.00542-11

[59] Steenkamp, E.T., Stepkowski, T., Przymusiak, A., Botha, W.J. and Law, I.J. (2008) Cowpea and Peanut in Southern Africa Are Nodulated by Diverse Bradyrhizobium Strains Harbouring Nodulation Genes that Belong to the Large Pantropical Clade Common in Africa. Molecular Phylogenetics and Evolution, 48, 1131-1144. https://doi.org/10.1016/j.ympev.2008.04.032

[60] Zhang, Y.F., Wang, E.T., Tian, C.F., Wang, F.Q., Han, L.L., Chen, W.F. and Chen, W.X. (2008) Bradyrhizobium elkanii, Bradyrhizobium yuanmingense and Bradyrhizobium japonicum Are the Main Rhizobia Associated with Vigna unguiculata and Vigna radiata in the Subtropical Region of China. FEMS Microbiology Letters, 285, 146-154. https://doi.org/10.1111/j.1574-6968.2008.01169.x

[61] Zilli, J.E., Valisheski, R.R., Filho, F.R.F., Neves, M.C.P. and Rumjanek, N.G. (2004) Assessment of Cowpea Rhizobium Diversity in Cerrado Areas of Northeast Brazil. Brazilian Journal of Microbiology, 35, 281-287. https://doi.org/10.1590/S1517-83822004000300002

[62] Saleena, L.M., Loganathan, P., Sunita, R. and Nair, S. (2001) Genetic Diversity and Relationship between Bradyrhizobium Strains Isolated from Black Gram and Cowpea. Biology and Fertility of Soils, 34, 276-281.

https://doi.org/10.1007/s003740100391 
[63] Yokoyama, T.N., Tomooka, N., Okabayashi, M., Kaga, A., Boonkerd, N. and Vaughan, D.A. (2006) Variation in the Nod Gene RFLPs, Nucleotide Sequences of 16S rRNA Genes, Nod Factors, and Nodulation Abilities of Bradyrhizobium Strains Isolated from Thai Vigna Plants. The Canadian Journal of Microbiology, 52, 31-46. https://doi.org/10.1139/w05-099

[64] Wade, T.K., Le Quere, A., Laguerre, G., N’Zoue, A., Ndione, J.-A., Dorego, F., Sadio, O., Ndoye, I. and Neyra, M. (2014) Eco-Geographical Diversity of Cowpea Bradyrhizobia in Senegal Is Marked by Dominance of Two Genetic Types. Systematic and Applied Microbiology, 37, 129-139.

https://doi.org/10.1016/j.syapm.2013.10.002

[65] Guimarães, A.A., Duque Jaramillo, P.M., Abrahao Nobrega, R.S., Florentino, L.A., Silva, K.B. and de Souza Moreira, F.M. (2012) Genetic and Symbiotic Diversity of Nitrogen Fixing Bacteria Isolated from Agricultural Soils in the Western Amazon by Using Cowpea as the Trap Plant. Applied and Environmental Microbiology, 78, 6726-6733. https://doi.org/10.1128/AEM.01303-12

[66] Batista, L., Irisarri, P., Rebuffo, M., Jose Cuitino, M., Sanjuan, J. and Monza, J. (2015) Nodulation Competitiveness as a Requisite for Improved Rhizobial Inoculants of Trifolium pratense. Biology and Fertility of Soils, 51, 11-20. https://doi.org/10.1007/s00374-014-0946-3

[67] Payakapong, W., Tittabutr, P., Teaumroong N. and Boonkerd, N. (2004) Soybean Cultivars Affect Nodulation Competition of Bradyrhizobium japonicum Strains. World Journal of Microbiology and Biotechnology, 20, 311-315. https://doi.org/10.1023/B:WIBI.0000023838.06663.c5

[68] Sivasakthi, S., Saranraj, P. and Sivasakthivelan, P. (2019) Beneficial Effect of Bradyrhizobium sp. on Black Gram (Vigna mungo L.) Cultivation: A Review. Life Science Archives (LSA), 3, 1195-1206.

[69] Teamroong, N. and Boonkerd, N. (2006) Rhizobial Production Technology. In: Ray, R.C., Ed., Microbial Biotechnology in Agriculture and Aquaculture, Volume 2, Science Publishers, New York.

[70] Wani, S.P., Rupela, O.P. and Lee, K.K. (1995) Sustainable Agriculture in a Semiarid Tropic through Biological Nitrogen Fixation in Grain Legume. Plant \& Soil, 174, 29-49. https://doi.org/10.1007/BF00032240 